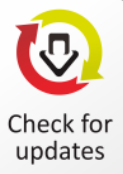

updates

Article Type: Research Paper

\title{
Success Factors of Village-Owned Enterprises (BUMDes) Performance in Indonesia: An Exploratory Study
}

\author{
Hafiez Sofyani ${ }^{1 *}$, Randi Atmaja ${ }^{1}$, Sri Budhi Rezki ${ }^{1}$
}

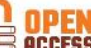

\section{AFFILIATION:}

${ }^{1}$ Department of Accounting, Universitas Muhammadiyah Yogyakarta, Daerah Istimewa Yogyakarta, Indonesia.

\section{*CORRESPONDENCE:}

hafiez.sofyani@umy.ac.id

THIS ARTICLE IS AVAILABLE IN:

http://journal.umy.ac.id/index.php/ai

DOI: 10.18196/jai.2002116

\section{CITATION:}

Sofyani, H., Atmaja, R., \& Rezki, S. B. (2019). Success Factors of Village-Owned Enterprises (BUMDes) Performance in Indonesia: An Exploratory Study. Journal of Accounting and Investment, 20(2), 44-58.

\section{ARTICLE HISTORY}

Received:

16 December 2018

Reviewed:

8 January 2019

Revised:

10 April 2019

Accepted:

20 April 2019
ABSTRACT: The full autonomy given to village governments by the Indonesian government coming with the demand to establish Village-Owned Enterprises (BUMDes) brings both opportunities and challenges. The reason is that not all BUMDes which have been established could perform satisfactorily. In fact, out of 3900 existing BUMDes, only a small percentage showed satisfactory performance. Based on this background, this research aims to investigate key success factors which drive the performance of BUMDes. The research was conducted from November to December 2018. The research subjects were BUMDes Amarta, Srimartani Makmur, and Tirtonirmolo, which are located in the Special Region of Yogyakarta, Indonesia. These three BUMDes were chosen because they serve as a benchmark for how BUMDes in Indonesia should be managed. The research informants were directors and employees of these BUMDes where each BUMDes was represented by one director and one employee. The data were obtained from direct interviews and documentation. The data were analyzed using a qualitative approach, consisting of such steps as data reduction, data display and conclusion drawing. The results indicated that the factors that drive the performance of BUMDes were BUMDes employees' patriotism and passion, skills, training, level of education, experience, honesty (ethical behavior), having a sense of responsibility, sincerity, seriousness, caring for the environment and society, being resilient, cohesiveness of teamwork, transparent communication between BUMDes managers, never-give-up attitude in trying to achieve the performance targets, religiosity, work satisfaction, visionary (transformational) leadership style, and the presence of incentive mechanisms.

KEYWORDS: village-owned enterprise (bumdes); success factors; performance; village government

\section{Introduction}

One of the Indonesian government's missions in developing rural areas is to empower the community and this will eventually improve productivity and diversity of businesses in rural areas. This is intended to allow villages to have the facilities and infrastructures to support their economic activities independently, build and strengthen the institutions which 
support the production and marketing chains, as well as optimize the resources as the basis for rural economic growth (Tama, 2013). Being less effective, the economic institutional system and mechanism will result in its dependence on the central government's assistance and, thus, stultify the villages' spirit to be independent (Tama, 2013). To achieve the regional government's ideal of advancing and developing villages, the village governments should apply a strategy in managing its administration to maximize its potentials to support people's better lives, particularly in socio-economic and political fields (Fajarwati, 2016).

The spirit of local economic democracy in Indonesia at the village government level began to be realized when Law Number 23 the Year 2014 concerning Regional Government was issued. This regulation assigned equal positions to villages and tier III regions (regency/ municipality). The independence of village government is strengthened further by Law Number 6 the Year 2014 concerning Village (labeled as Village Law). Thanks to this regulation, village government is now fully independent to manage and build their government, and one of the efforts they can do to realize this is to establish BUMDes (Badan Usaha Milik Desa or Village-owned Enterprises).

BUMDes is born as a new approach to the attempt to improve the economy in villages according to their own needs and potentials. This BUMDes is fully managed by the village's people using the principle of from the village, by the village and for the village. BUMDes works by accommodating people's economic activities in an institutional form or entity managed professionally, yet the basis for all these remain the village's original potentials. This BUMDes is the village's business incorporated/established by the village government where the capital is owned and managed by the village government and its people. BUMDes is expected to stimulate and drive the economic wheel in rural areas which have so far been left behind as compared to their urban counterparts (Ramadana, 2013).

BUMDes have been a significant presence in Indonesia upon the enactment of Village Law. In 2018, 39,000 BUMDes had been recorded in villages throughout the country ${ }^{1}$. In reality, however, not all BUMDes succeeded. In the field, many have found the incorporated BUMDes were operating only for a short run². From our observation, it was found that there was a highly limited number of research on BUMDes had been conducted, particularly ones which viewed it from the managerial and performance aspects. This is quite surprising considering the importance of studies on the factors which enable a BUMDes to succeed to produce some feedbacks for BUMDes practitioners and regulators.

On the other hand, a huge number of newly born BUMDes indicate the vast amount of money invested by the government. When BUMDes fails, the village's ideal to be independent would be beyond the reach even further. On the contrary, what happened were wasting the country's assets and financial inefficiency. Furthermore, it is highly likely that this will weaken the village government institution and cause a new issue at

1 https://nasional.kontan.co.id/news/saat-ini-jumlah-bumdes-telah-meningkat-menjadi-39000

2 http://manado.tribunnews.com/2017/04/04/linda-bumdes-hanya-aktif-sesaat 
the national level in Indonesia. Therefore, this research tries to fill in the absence of study on BUMDes, in this case by studying the determinants of BUMDes's performance. The current research aims mainly to explore the factors (determinants) of BUMDes' performance so that it could provide feedbacks, information, and reference regarding some essential aspects which are needed to be highlighted to enhance BUMDes's performance.

This research involved three BUMDes with different characteristics in terms of their lines of business and locations. The first one wasBUMDes Amarta which ran its business in the services of managing and recycling wastes into fertilizers, both organic and inorganic ones. The second one was BUMDes Srimartani Makmur, located in Srimartani Village, Piyungan Sub-district, Bantul Regency, running its business in selling products from Micro, Small and Medium Enterprises around its area by establishing the village outlet. The products it marketed varied, ranging from handicrafts such as batik and knitted wears to packed processed food products such as banana crisp to ready-to-use instant seasoning products and herbal products such as instant herb and herbal drinks (Prisa, 2018). The last one was BUMDes Tirtonirmolo which was located in Tirtonirmolo Village, Kasihan District, Bantul Regency. These three BUMDes were selected for their good performance and for the fact that they were role models for how BUMDes in Indonesia should be managed. Thus they served the purposes of this research ${ }^{3}$.

Since this research investigates a relatively new topic and aims at exploring the factors which support the success of several BUMDes, we opted to use the interview-based qualitative research approach. It is expected that this research's findings will benefit the society in general and contribute to the science and knowledge of management practices and the efforts of achieving a good performance in BUMDes. For other BUMDes, the results of this research can be feedbacks in their attempt of improving their performance.

\section{Literature Review}

\section{Village Regulation in Indonesia}

The development of Indonesia will be optimal if it takes into account the strategic position of villages as the backbone of life of Indonesia. Thus, using Law Number 23 the Year 2014 concerning Regional Government, Indonesia's government endeavors to manage village decentralization mechanism to develop villages according to the characteristics and potentials of each village. In addition to having its basis on the central government's policy, as suggested by Widodo (2016), the development of villages should also be accompanied by involvement of all village members to achieve the village's common goals. One of the mechanisms people can implement is by presenting a village-owned enterprises or BUMDes.

http://jogja.tribunnews.com/2013/09/24/hebat-badan-usaha-milik-desa-tirtonirmolo-beromzet-miliaranrupiah 
The presence of Village Law is expected to allow villages to be powerful socially and economically, sovereign politically, and dignified culturally which is also known as Catur Sakti Desa or Village's Four Dignity Principles when applied well (Widagdo, Widodo, \& Ismail, 2016). The Village Law is also expected to answer the numerous problems in villages which include socio-cultural and economic aspects and to recover village's people livelihood basis and strengthen villages as a strong and independent societal entity (Widagdo et al., 2016).

\section{Village-Owned Enterprises (BUMDes)}

In accordance with Law Number 6 the Year 2014 on Village Article 1 paragraph 6, it is stated as follows:

"Village-Owned Enterprises, hereinafter referred to as BUM Desa, is a business entity whose capital is owned entirely or partly by villages through direct investment from village's wealth which is separated in order to manage assets, services, and other businesses for the village people's greatest possible welfare."

The establishment and management BUMDes constitute the implementation of village's productive economic management performed in a cooperative, participatory, emancipative, transparent, accountable, and sustainable manner (Suryanto, 2018). For this purpose, there is the need for a serious attempt in making the BUMDes management effective, efficient, proportional and independent. In accordance with Regulation of Ministry of Villages, Development of Disadvantaged Regions and Transmigration Number 4 the Year 2015 concerning Establishment, Administration and Management, and Dismission of Village-Owned Enterprises Article 3, it is suggested that the establishment of BUMDes aims at:

1) Improving the village's economy;

2) Optimizing the village's assets to be used for its welfare;

3) Improving people's attempt in managing the village's economic potentials;

4) Developing a business partnership plan between villages and/or third parties;

5) Creating market opportunities and networks which support the people's services needs;

6) Creating job opportunities;

7) Increasing people welfare by improving public services and village economic growth and equality; and

8) Increasing village people's income and Village's Locally Generated Revenue."

In addition to those objectives, BUMDes is also expected to provide services to as many villagers as possible. Hence, BUMDes is never intended to compete with the villagers. In reality, BUMDes is prohibited from running any business which would create economic distortion in the villages, for example selling products or building a business which have 
previously been initiated by the villagers. Rather, BUMDes should be capable of pioneering the attempt to increase the scale of villagers' existing businesses (Suryanto, 2018).

\section{BUMDes Management Principles}

It is important to elaborate the BUMDes management principles to align people's understanding and perception of it, including the village government, members (investors), Village Supervisory Board, Regency Government, and the community. According to Ridlwan (2014), there are 6 (six) principles in managing BUMDes, namely:

1) Cooperative, all components involved in BUMDes should be capable of cooperating well for developing and sustaining its businesses.

2) Participatory, all components involved in BUMDes should be voluntarily willing or asked to give the support and contribution which can drive BUMDes's business advancement.

3) Emancipatory, all components involved in BUMDes should be treated equally, regardless of their groups, ethnics, and religions.

4) Transparent, any activity which may affect the public interests should be made easily and transparently accessible for the whole community to figure it out.

5) Accountable, all business activities should be made accountable both technically and administratively, and

6) Sustainable, the business activities should be developable and preservable by the community within BUMDes.

\section{Research Method}

\section{Research Subjects and Informants}

The subjects of this research were BUMDes Srimartani Makmur and Tirtonirmolo, Amarta, located in the Special Region of Yogyakarta Province, Indonesia. The reasons and considerations for selecting these BUMDes as the subjects of this research were that those three BUMDes had succeeded in the Province and they had been role models on how BUMDes in Indonesia should be managed. The informants of this research were directors and employees of each BUMDes, making a total of six informants (see Table 1).

Table 1 Unit of Data Analysis

\begin{tabular}{clcc} 
No. & Unit of Data Analysis & Research Informants & Position \\
\hline 1 & BUMDes Amarta & DBA \& PBA & 1 Director \& 1 Employee \\
2 & BUMDes Srimartani Makmur & DBS \& PBS & 1 Director \& 1 Employee \\
3 & BUMDes Tirtonirmolo & SBT \& PBT & 1 Director \& 1 Employee \\
& TOTAL & & $\mathbf{6}$ Informants \\
\hline
\end{tabular}




\section{Data Collection and Analysis}

The data used in this research were primary ones, obtained from an in-depth interview conducted in person in November and December 2018, and several documentations directly related to the BUMDes management, such as performance report, organizational structure, statutes, and bylaws. The data in this research were analyzed using an interactive model (Eriksson \& Kovalainen, 2008; Long \& Johnson, 2000; Miles, Huberman, Huberman, \& Huberman, 1992). The processes of qualitative analysis can be explained in three steps:

1) Data reduction, a process of selecting, focusing attention to simplification, abrasion, and transformation of raw data obtained from the field.

2) Data display, a description of a structured series of information from which conclusion can be drawn, and actions can be taken. A commonly used qualitative data display is in the form of narrative texts.

3) Conclusion drawing and verification from initial activities, i.e., data collection, qualitative researchers will interpret every symptom they obtain from the field, recording information on rules or pattern of explanation and configuration they might find, the flow of causality and proposition. A competent researcher will handle with these conclusions loosely to remain open and skeptical, yet conclusions have been prepared. During the research, each one of the existing conclusions will be constantly verified in such a way that valid and robust conclusions can actually be obtained.

The data obtained from the field require specific treatment in order to obtain the data which match the predetermined standards. For this purpose, the obtained data need to be individually recorded, sorted, presented and only then can conclusions be drawn from the data obtained through observation, interview, and documentation.

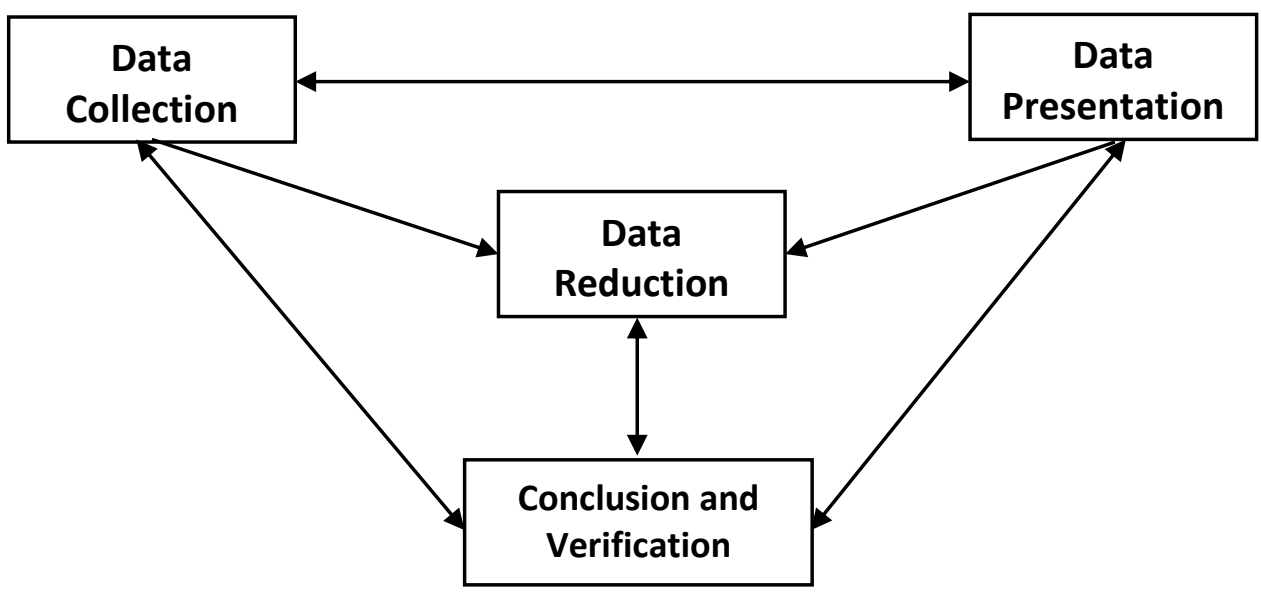

Figure 1 The Components of Interactive Model Data Analysis

Source Miles et al. (1992), p. ? 


\section{Result and Discussion}

This research was conducted to three BUMDes in the Special Region of Yogyakarta Province. The first one was BUMDes Amarta. BUMDes Amarta is situated in Pandowoharjo Village, Sleman Subdistrict, Sleman Regency, established on 6 June 2016. Before becoming a village-owned enterprise, it was initially a waste recycling business unit in Pandowoharjo Village under the name "Pendowo Lestari", which was a grant from the Office of Public Works of Bantul Regency. BUMDes Amarta tried to develop the available opportunity by incorporating an entity running its business in processing wastes from the community of Pandowoharjo Village. The task of picking the wastes in BUMDes Pandowoharjo was done by Pengumpul Sampah Mandiri (PSM) or Independent Waste Collectors who were partners of BUMDes Amarta from Pandowoharjo community. The collected wastes were sorted into organic and inorganic wastes. The organic waste was then processed into fertilizers, and the inorganic one was sold to waste collectors through cooperation. With the collectively agreed vision and missions, BUMDes Amarta could turn into a BUMDes with excellent performance at its relatively young age. They excelled not only in their financial performance but also in terms of cleaning their village's environment and turning it into job vacancies for the villagers.

BUMDes Srimartani Makmur is located in Srimartani Village, Piyungan District, Bantul Regency. This BUMDes was established since 28 November 2016 with six business lines managed by it, including; village market management, display of UKM products which were marketed via village outlet, services (E-Warung, PPOB), integrated waste management, modern horticultural farming laboratory, and clean water management which were supported by seven employees consisting of three managers, and four employees.

The last one is BUMDesa Tirtonirmolo. Initially, this BUMDes was an Usaha Ekonomi Desa (UED) or village economic business established since 1988 before it changed its name into Unit Simpan Pinjam (USP) or Saving and Lending Unit "Sedya Makmur". The initial capital of UED came from the village government incentive at Rp. 1 million through Bantuan Desa (Bandes) or village assistance scheme. Currently, BUMDes Tirtonirmolo's turnover has reached IDR 8.7 billions a year. Thanks to BUMDes management, all of Tirtonirmolo villagers' needs can be fulfilled. The amount of assets it manages is around Rp. 11 billions. Currently, the number of loan customers is 1,900 people, $10 \%-15 \%$ of whom are owners of basic food and convenience store SMEs.

\section{Factors Influencing BUMDes Performance}

In Gibson's (1997) opinion, an organization's performance is influenced by three main factors, namely: (1) Individual factors, including work experience, skills, and education level; (2) Psychological factors, including employee's personality and work satisfaction; and (3) Organizational factors, including leadership, organizational structure, and incentive mechanism. From this Gibson's (1997) opinion, we then make it the basis in exploring the determinants of BUMDes performance. 
Individual Factor

From individual factors, the one capable of driving BUMDes Amarta, Srimartani Makmur, and Tirtonirmolo to have a good performance was their employees' strong desire to contribute to their villages. The employees in these three BUMDes acknowledged that their willingness in the management of BUMDes were not merely for the income (salary) they would receive, rather it was their strong desire to do something good to the community, through BUMDes. This was also rooted in their love to their villages, or we could also call it their patriotism spirit (Nazaruddin, 2019), making them do it for intrinsic motivation purpose. This was consistent with the motivation theory explained by Locke and Latham (2004) who suggested that one of the determinants for an individual to do something good was their own believe that what they did was the right and good thing to do which gave benefit to themselves and their social environment (Ridlwan, 2014). This was also consistent with the ideal of the Indonesian government in relation to the establishment of BUMDes, i.e. it did not just aim for profit, rather it should also benefit the surrounding community. Below is a quote from informant DBA:

"...my goal for working in this BUMDes is to participate in developing Pandowoharjo Village with its existing potentials. The point is that I want to contribute to the village I love". (DBA)

The opinion above was also consistent with what PBA said.

"I worked here not just for the money/salary; rather I do want to help the villagers here...". (PBA)

In addition to their patriotism spirit, what drives an organization's performance is the employee's skills. The skills owned by employees will improve the effective and efficient implementation of work plans. To improve this skill, training should be organized just as what BUMDes Amarta did periodically.

“....employee skill training will help improve BUMDes's performance, such as those working in fertilizer processing should have the skills on how to process fertilizers well, just like in any other field." (DBA)

The importance of skill and training presence in supporting BUMDes's employee skills which, in turn, will improve BUMDes's performance was also uttered by an employee in BUMDes Srimartani Makmur as follows:

"I was demanded to be capable of operating the computer, and this is supported as training is organized periodically here. Since the financial reporting system used here employs the application, it is inevitable for one working here to understand the computer. In this BUMDes, skills are highly needed". (PBS)

Furthermore, we tried to explore whether this skill issue was also related to BUMDes employees' education level. This was because several references suggested that 
education could influence the performance of an organization, particularly in an institution which required HR with high education levels such as offices and financial institution (Soriano \& Castrogiovanni, 2012). For BUMDes Amarta's case, education did not seem to be the dominant factor. Our finding showed that BUMDes Amarta did not prioritize one's education level to be able to work in BUMDes. This was as stated by Mister Agus as the Director of BUMDes Amarta as follows:

"the employees in BUMDes Amarta do not have to have a certain education level, most importantly they should be willing to work, highly motivated, and discipline. That's all it takes, no certain diploma is required, since well it is just it (making fertilizers), thus you should not be a graduate of this or that university (to work here)". (DBA)

However, this finding was different from what we found in BUMDes Srimartani Makmur and Tirtonirmolo. The informants in these two BUMDes thought education level was a highly important and deciding factor.

"....here, we need employees whose education level is high school, since it is expected that quality personnel will improve BUMDes's performance better. If you select the personnel randomly, then you'll get random management". (DBS)

"to compete in the future, high education level is certainly needed, and it is also the case with BUMDes Tirtonirmolo". (SBT)

Based on the interviews with informants from BUMDes Amarta, BUMDes Srimartani Makmur, and BUMDes Tirtonirmolo, it could be concluded that education did not always serve as a priority for a BUMDes to hire an employee, particularly BUMDes Amarta whose business was processing wastes. This was not the case with BUMDes Srimartani Makmur and BUMDes Tirtonirmolo who demanded their employees to have a certain education level since BUMDes Srimartani Makmur ran its business in village outlet which had employed a computerized system to report their finance, and BUMDes Tirtonirmolo whose line of business was saving and lending fund where the employees were required to have expertise in accounting and financial management. From this finding, it could be concluded that whether the education level was important or not depended on the line of business ran by a BUMDes.

Moreover, we also found that experience became an important factor in improving BUMDes's performance, just as what happened in Srimartani Makmur. BUMDes employee's experience did not just have something to do with improved competence and expertise in managing an organization; rather it could also be knowledge for other younger employees through knowledge sharing session. From here on, a senior's experience would be transferred to their juniors, and it would improve personnel quality and eventually trigger the organization's performance improvement (Schmidt, Hunter, \& Outerbridge, 1986). Below are the statements from BUMDes Srimartani Makmur director and employee: 
“....work experience is highly needed in this BUMDes, where experienced personnel can be a model for others to learn from so that we can share knowledge among us". (DBS)

"I happen to be a recruit here. Thus I lack experience... However, I learn from the more experienced seniors here... When I work not too well, the seniors here will tell me and teach me the right way of doing it...". (PBS)

Furthermore, another aspect which became the main determinant in driving an organization's performance was employee honesty (ethical behavior). This was just reasonable given that BUMDes Tirtonirmolo ran its business in finance, i.e., as a saving and lending cooperative. Many researchers had explained ethical behavior as an important factor in achieving an organization's performance (Lagace, Dahlstrom, \& Gassenheimer, 1991; Román, 2003). Román and Ruiz (2005) argued that subordinate's ethical behavior at work did not just drive performance achievement; it also caused customer satisfaction and loyalty to purchase the products the company offered. Thus, the organization's performance would not just improve; it would also be maintained.

"I have worked here since 1991, the value I learn as work experience is that one should learn to be honest since it is the people's money we are managing. Thus, we ought to be trustworthy". (SBT)

\section{Psychological Factor}

In this psychological factors, we tried to explore the personality and work satisfaction of BUMDes employees. Based on the interviews with two informants from BUMDes Amarta, four factors related to psychological aspect or personality of BUMDes employees which supported BUMDes's performance were found, namely: being responsible, sincere, serious, and caring the environment and community. The first one was being responsible, meaning that every employee should be committed to perform each task assigned to them optimally. The second was being sincere, meaning that every employee should work sincerely and with strong intention to develop the village potentials and help the community. The third one was being serious, meaning that BUMDes Amarta employees should be capable of working seriously, professionally and devoting their focus on achieving BUMDes Amarta's vision, i.e., to realize the welfare of Pandowoharjo villagers by developing the village potentials and economic attempts to make Pandowoharjo villagers prosperous and independent. The fourth one was that employees should care about the environment and community of Pandowoharjo Village.

"....I see an employee's personality who is willing to care the environment, care the community, and has a social soul as something which would drive our BUMDes forward...". (DBS)

Meanwhile, the finding in BUMDes Srimartani Makmur emphasized more on such aspects as perseverance, teamwork togetherness, transparent commu-nication among BUMDes managers, and never give up in trying to achieve the performance target. 
Sofyani, Atmaja \& Rezki

Success Factors of Village-Owned Enterprises (BUMDes) Performance in Indonesia

Finally, there is an interesting finding in BUMDes Tirtonirmolo. This BUMDes saw its good performance coming from its administrator's religiosity, where pious personnel led to honest and trustworthy attitudes. This was highly important since this BUMDes ran its business in finance, i.e., saving and lending services, whose main tasks was to manage the people's money.

Based on the interview with the three BUMDes, it could be concluded that the good performance of these BUMDes was influenced by the personality factor in each BUMDes with their varied characteristics. However, the have something in common, where employees with perseverance, highly caring (to the environment), and ethical personality is highly needed in an organization, particularly those organizations dealing with social issues such as BUMDes since it would indirectly affect the good performance achievement.

The next step to measure BUMDes performance based on psychological factors used work satisfaction as the measuring tool. Every employee had varied work satisfaction based on their individual needs which had been fulfilled through several factors such as the job itself, supervisors, coworkers, and salary (Christen, Iyer, \& Soberman, 2006). Based on the interview with the three BUMDes, we found that the main factor related to the work satisfaction of BUMDes activitists was the BUMDes employees' satisfaction to the job and this eventually drove the performance of the three BUMDes forward. The satisfaction we found here was the attitude of those individuals motivated to be BUMDes activists not just for profit or material benefit, rather it was for their desire to contribute to their society, in this case, their villages. When BUMdes performed well, the employees were satisfied and more motivated to keep on performing.

\section{Organizational Factor}

To measure the organizational factor, we used two measuring tools, namely leadership, and incentive mechanism. Leadership became a determinant factor in improving the subordinates' performance. A visionary and dignified leader who could be a role model for the employees in the organization could drive their subordinates more geared up to work and be disciplined, and vice versa. From our finding in the field in the three BUMDes we studied, their directors had a transformational leadership style. In the transformational leadership context, leaders had a highly strong vision and clear goals. The BUMDes leaders could communicate this vision effectively since they knew the strengths and they could utilize them (Wang, Oh, Courtright, \& Colbert, 2011). This was consistent with Ogbonna and Harris (2000) who suggested that positive and strong leadership could influence BUMDes performance, i.e. when leaders could be a role model for good characteristics, had clear vision and missions, and were firm, then they could motivate employees in BUMDes to work well and to be expected to improve BUMDes's performance (McColl-Kennedy \& Anderson, 2002; Wang et al., 2011).

"We are grateful for our leaders here who have strong characters, clear vision, and missions, and can motivate as well as be role models for their subordinates".

(DBS) 
Sofyani, Atmaja \& Rezki

Success Factors of Village-Owned Enterprises (BUMDes) Performance in Indonesia

Next, we would discuss about incentive factors. This mechanism was deemed to have a significant influence on employees' and, in turn, the organization's performance. The incentive applied in these BUMDes was intended to motivate employees to work and perform as best as they could. Additionally, the reward could make employees feel at home as they work and prevent them from switching to another organization.

"....when you work optimally here, and the targets can be met, you can sometimes land yourself a bonus. Also holiday allowance is available, even if it's well... not too much yet it can still be a little bit helpful, it still makes us happy for having additional income. This also improves employees' desire to work". (PBA)

Nevertheless, from these three research object of ours, only BUMDes Srimartani Makmur had not applied the incentive mechanism for it is relatively newly established and had not been strong enough financially. This finding indicated that incentive mechanism was indeed needed to support performance (Cooke, 1994; Merchant \& Van der Stede, 2007), yet it is equally important to consider BUMDes's financial health to prevent them from having financial liquidity issues (Brigham \& Houston, 2012; Horne, 2001). The development of an incentive mechanism at the end of the day needed to be done using careful consideration, and taking the BUMDes's internal condition into account.

\section{Conclusion}

This research explored how BUMDes could perform well as measured from three benchmarks, namely individual, psychological and organizational factors (Gibson, 1997). The BUMDes serving as objects of this research were three BUMDes located in the Special Region of Yogyakarta, they were BUMDes Amarta in Pandowoharjo Village, Sleman Regency, BUMDes Srimartani Makmur in Srimartani Village, Bantul Regency, and BUMDes Tirtonirmolo in Tirtonirmolo Village, Bantul Regency. Based on the results of the conducted research, some factors were found to drive BUMDes Amarta to perform well, namely the patriotism and passion of BUMDes employees, skills, training, education level, experience, honesty (ethical behaviour), being responsible, sincere, serious, caring the environment and community, and perseverant, teamwork togetherness, transparent communication among BUMDes managers, never-give-up attitude in trying to achieve the performance target, being religious, satisfaction at work, visionary (transformational) leadership style, and presence of incentive mechanism.

From the findings of this research, the practical implications we can offer for other BUMDes in Indonesia are: firstly, BUMDes administrators and employees should possess patriotism since in essence BUMDes is intended not just for economic motive, rather it also assumes social missions or interests, where they work aiming at developing the villages' existing potentials and to serve the community at the same time. Secondly, BUMDes should organize training periodically to improve their employees' skills. Thirdly, BUMDes whose business lines require excellent understanding shall recruit personnel 
with adequate education levels, and BUMDes whose business lines do not really demand excellent understanding do not necessarily need them. Fourthly, it is important to present a leadership capable of becoming a role model for employees. In the case of the three BUMDes, they tend to have a charismatic leadership style. Finally, the incentive mechanism is important to nurture employees' passion for performing. However, it needs to carefully consider the BUMDes internal condition, particularly regarding financial power. Still, it is necessary for the parties involved in BUMDes management to carefully consider whether or not the time has come to procure incentive mechanism.

This research has some limitations, and it is expected that future research can fix it, The first limitation is that not too many studies have been conducted to investigate villageowned enterprises, particularly the village-owned enterprises in the Special Region of Yogyakarta, preventing researchers from exploring it a little bit further. Secondly, this research does not represent the conditions of all BUMDes in Indonesia since each BUMDes has its own diverse characteristics. Lastly, this research is not a longitudinal stud. Thus it needs to be read carefully. From these limitations, the future research is expected to expand the study to other BUMDes in Indonesia since this constitutes an important issue to be continuously investigated, particularly to provide feedbacks to the regulator in the village and BUMDes development. Other research approaches such as etnography, action research, survey, and mixed-method are strongly recommended (Sofyani, 2018).

\section{Acknowledgement}

I (Hafiez Sofyani) representing all colleagues acknowledge and devote many thanks to the late Sri Budhi Rezki, SE., M.Sc, a lecturer of accounting at Universitas Muhammadiyah Yogyakarta, Indonesia. May her spirit calm on side of Allah Subhanahu wa Ta'aala.

\section{References}

Brigham, E. F., \& Houston, J. F. (2012). Fundamentals of financial management: Cengage Learning.

Christen, M., Iyer, G., \& Soberman, D. (2006). Job satisfaction, job performance, and effort: A reexamination using agency theory. Journal of Marketing, 70(1), 137-150. https://doi.org/10.1509/jmkg.70.1.137.qxd

Cooke, W. N. (1994). Employee participation programs, group-based incentives, and company performance: A union-nonunion comparison. ILR Review, 47(4), 594-609. https://doi.org/10.1177/001979399404700405

Eriksson, P., \& Kovalainen, A. (2008). Qualitative research in business studies. London: Sage Publication.

Fajarwati, Y. (2016). Implementasi Program Badan Usaha Milik Desa (BUMDesa) di Desa Pagedangan Kecamatan Pagedangan Kabupaten Tangerang. Research Report. Fakultas Ilmu Sosial dan Ilmu Politik. Universitas Sultan Ageng Tirtayasa. Serang. 
Gibson, J. (1997). Organisasi dan manajemen: Perilaku, struktur, sroses. Jakarta: Binarupa Aksara.

Horne, J. C. V. (2001). Financial Management and Policy. New Jersey: Prentice-Hall, Inc, Upper Saddle.

Lagace, R. R., Dahlstrom, R., \& Gassenheimer, J. B. (1991). The relevance of ethical salesperson behavior on relationship quality: The pharmaceutical industry. Journal of Personal Selling \& Sales Management, 11(4), 39-47. Retrieved from https://s3.amazonaws.com/academia.edu.documents/46166671/The Relevance o f Ethical Salesperson Beh20160602-217561e49tj6.pdf?AWSAccessKeyId=AKIAIWOWYYGZ2Y53UL3A\&Expires=155668 9013\&Signature $=\mathrm{Mzg}$ 2 $2 \mathrm{kulqQI} 7 \mathrm{Ad} 9 \mathrm{zx} \% 2 \mathrm{Fo} 6 \mathrm{JSm} 0 \mathrm{i} 7 \mathrm{k} \% 3 \mathrm{D} \&$ response-contentdisposition $=$ inline $\% 3 \mathrm{~B} \% 20$ filename $\% 3 \mathrm{DTh}$ The relevance of ethical salesperson be $\underline{\text { h.pdf }}$

Locke, E. A., \& Latham, G. P. (2004). What should we do about motivation theory? Six recommendations for the twenty-first century. Academy of Management Review, 29(3), 388-403. https://doi.org/10.5465/amr.2004.13670974

Long, T., \& Johnson, M. (2000). Rigour, reliability and validity in qualitative research. Clinical effectiveness in nursing, 4(1), 30-37. https://doi.org/10.1054/cein.2000.0106

McColl-Kennedy, J. R., \& Anderson, R. D. (2002). Impact of leadership style and emotions on subordinate performance. The Leadership Quarterly, 13(5), 545-559. https://doi.org/10.1016/s1048-9843(02)00143-1

Merchant, K. A., \& Van der Stede, W. A. (2007). Management control systems: performance measurement, evaluation and incentives: Pearson Education.

Miles, M. B., Huberman, A. M., Huberman, M. A., \& Huberman, M. (1992). Qualitative data analysis. USA: sage.

Nazaruddin, I. (2019). The Role of Religiosity and Patriotism in Improving Taxpayer Compliance. Journal of Accounting and Investment, 20(1), 115-129. https://doi.org/10.18196/jai.2001111

Ogbonna, E., \& Harris, L. C. (2000). Leadership style, organizational culture and performance: empirical evidence from UK companies. International Journal of Human Resource Management, 11(4), 766-788. https://doi.org/10.1080/09585190050075114

Ramadana, C. B. (2013). Keberadaan Badan Usaha Milik Desa (BUMDES) sebagai Penguatan Ekonomi Desa. Jurnal Administrasi Publik, 1(6), 1068-1076. Retrieved from http://administrasipublik.studentjournal.ub.ac.id/index.php/jap/article/view/189

Ridlwan, Z. (2014). Urgensi Badan Usaha Milik Desa (BUMDes) dalam Pembangun Perekonomian Desa. Jurnal Ilmu Hukum, 8(3), 424-440. https://doi.org/10.25041/ fiatjustisia.v8no3.314

Román, S. (2003). The impact of ethical sales behaviour on customer satisfaction, trust and loyalty to the company: An empirical study in the financial services industry. Journal of Marketing Management, 19(9-10), 915-939. https://doi.org/10.1080/0267257x.2003.9728245

Román, S., \& Ruiz, S. (2005). Relationship outcomes of perceived ethical sales behavior: the customer's perspective. Journal of Business Research, 58(4), 439-445. https://doi.org/10.1016/i.jbusres.2003.07.002

Schmidt, F. L., Hunter, J. E., \& Outerbridge, A. N. (1986). Impact of job experience and ability on job knowledge, work sample performance, and supervisory ratings of job performance. Journal of applied psychology, 71(3), 432. https:// doi.org/10.1037//0021$\underline{9010.71 .3 .432}$ 
Sofyani, H. (2018). Does Performance-Based Budgeting Have a Correlation with Performance Measurement System? Evidence from Local Government in Indonesia. Foundations of Management, 10(1), 163-176. https://doi.org/10.2478/fman2018-0013

Soriano, D. R., \& Castrogiovanni, G. J. (2012). The impact of education, experience and inner circle advisors on SME performance: insights from a study of public development centers. Small Business Economics, 38(3), 333-349. https://doi.org/10.1007/s11187-010-9278-3

Suryanto, R. (2018). Peta Jalan BUMDes (The Road Map of BUMDes) Yogyakarta: Syncore.

Tama, D., O, E. . (2013). Dampak Badan Usaha Milik Desa (BUMDES) Bagi Kesejabteraan Masyarakat Di Desa Karangrejek Kecamatan Wonosari Kabupaten Gunungkidul. Fakultas Ilmu Sosial. Universitas Negeri Yogyakarta. Yogyakarta.

Wang, G., Oh, I.-S., Courtright, S. H., \& Colbert, A. E. (2011). Transformational leadership and performance across criteria and levels: A meta-analytic review of 25 years of research. Group \& organization management, 36(2), 223-270. https://doi.org/10.1177/1059601111401017

Widagdo, A. K., Widodo, A., \& Ismail, M. (2016). Sistem Akuntansi Pengelolaan Dana Desa. Jurnal Ekonomi dan Bisnis, 19(2), 323-340. https://doi.org/10.24914/jeb.v19i2.336

Widodo, I. S. (2016). Village-Owned Enterprise (Badan Usaha Milik Desa) as One of the Alternative Sources of Village Revenue. Jumal Panorama Hukum, 1(1), 1-14.

\section{Regulation:}

Republic of Indonesia. (2014). Village Act 2014 No. 6 (Undang-undang Nomor 6 Tabun 2014 tentang Desa).

Republic of Indonesia. (2014). Village Government Act 2014 No. 23 (Undang-undang Nomor 23 Tabun 2014 tentang Pemerintahan Daerab).

\section{Article in Website:}

https://nasional.kontan.co.id/news/saat-ini-jumlah-bumdes-telah-meningkat-menjadi-39000 http://manado.tribunnews.com/2017/04/04/linda-bumdes-hanya-aktif-sesaat http://jogja.tribunnews.com/2013/09/24/hebat-badan-usaha-milik-desa-tirtonirmoloberomzet-miliaran-rupiah 